\title{
Solid pseudopapilar neoplasm of the pancreas
}

\section{Tumor sólido pseudopapilar de páncreas}

\author{
Walter Salinas*, Marcos Marani, Santiago Reimondez, Álvaro Alcaraz, Franco Signorini, \\ Martin Maraschio, y Enzo Giordano, and Lucio Obeide. \\ General Surgery Service, Hospital Privado Universitario de Córdoba, Córdoba, Argentina
}

\begin{abstract}
Solid pseudopapillary tumor of the pancreas is a rare entity, more frequent in women between the $2^{\text {nd }}$ and $4^{\text {th }}$ decades. The diagnosis is usually incidental and it can be reached by computed tomography or magnetic resonance imaging. Subsequent pathological confirmation is necessary for an adequate treatment. A retrospective study of six cases was carried out. All the patients were female, between 14 and 56 years of age, in which 50\% the tumor were an incidental finding. We had three cases located in the head and three in the body of the pancreas. We performed three pancreaticoduodenectomies and three distal pancreatectomies with splenic preservation, without disease recurrence.
\end{abstract}

Key words: Frantz tumor. Solid pseudopapillary neoplasm. Benign pancreatic tumors. Duodenopancreatectomy. Laparoscopic distal pancreatectomy

\section{Resumen}

El tumor sólido-quístico de páncreas es poco frecuente y predomina en mujeres entre la segunda y la cuarta décadas de la vida. Los pacientes son generalmente asintomáticos. El diagnóstico se realiza por imágenes con tomografía o resonancia magnética, y con la posterior confirmación patológica para poder ofrecer un tratamiento adecuado. Presentamos una serie de seis casos. Todas las pacientes fueron de sexo femenino, de entre 14 y 56 años. El 50\% fueron un hallazgo incidental. Tuvimos tres casos localizados en la cabeza y tres en el cuerpo del páncreas. Se realizaron tres duodenopancreatectomías cefálicas y tres pancreatectomías distales con preservación esplénica, con buena evolución y sin recidiva.

Palabras clave: Tumor de Frantz. Tumor sólido quístico pseudopapilar. Tumores pancreáticos benignos. Duodenopancreatectomía. Pancreatectomía corporocaudal laparoscópica.

\section{Introduction}

Frantz-Gruber tumor, also known as solid cystic tumor of the pancreas or pseudopapillary tumor, is a rare entity ${ }^{1}$, which represents $0.7-2.7 \%$ of all pancreatic tumors. It's more frequently observed between the $2^{\text {nd }}$ and $4^{\text {th }}$ decades of life and is more frequent in women².

The etiology is unknown, however, its distribution by age and sex is oriented to genetic and hormonal factors. The association of this disease with the use of oral contraceptives has not been demonstrated. The

\section{Correspondence:}

*Walter F. Salinas-Toconaz 
association of this disease with the use of oral contraceptives has not been demonstrated ${ }^{3,4}$.

Initial symptoms are non-specific and a high percentage of them correspond to incidental findings.

The imaging work-up includes computed tomography $(\mathrm{CT})$ and magnetic resonance imaging (MRI) that reveal solid cystic lesion well defined in the head or body of the pancreas ${ }^{5}$.

Histological confirmation is carried out with markers for vimentin, alpha-1-antitrypsin, CD-10, non-specific enolase, CD-56, and progesterone receptor (PR) ${ }^{6}$. The overall prognosis is good, with a 5-10 years survival greater than $90 \%$. Metastases have been reported in $10-15 \%$ of cases, most frequently to the peritoneum, greater omentum, liver, and regional lymph nodes. In the absence of metastasis, the main treatment is surgical resection ${ }^{4-8}$.

We present six cases of Frantz tumor treated by surgical resection in a third level hospital of our environment.

\section{Clinical cases}

\section{Case 1}

A 53-year-old female patient, with a history of hypertension, dyslipidemia, and hypothyroidism under medical treatment, came in with a 27-day history of epigastric pain, with elevation of liver enzymes (AST 169, ALT 491, and GGT 348), without cholestasis, tumor markers were $\mathrm{Ca}$ 19-92.2 U/ml. MRI reported a $3 \mathrm{~cm}$ diameter, nodular, regular lesion on the head of the pancreas with cystic areas, without vascular compromise or metastases (Table 1).

A pancreaticoduodenectomy with pyloric preservation was performed (Fig. 1). Hospital discharge was given on post-operative day 10 without complications. The histopathological analysis reported solid pseudopapillary tumor of $32 \times 28 \times 15 \mathrm{~mm}$, with free margins, seven lymph nodes without metastases. Inmunohistochemistry was positive for, alpha-1-antitrypsin, CD-10, CD-56, and PR. Last control at 34 months with CT without recurrence.

\section{Case 2}

A 16-year-old female patient, with a complaint of lower back pain. Ultrasound reveals an incidental lesion in the body of the pancreas. A CT was requested that confirmed a $10 \mathrm{~cm}$ lesion of the body of the pancreas, of solid appearance with areas of necrosis.

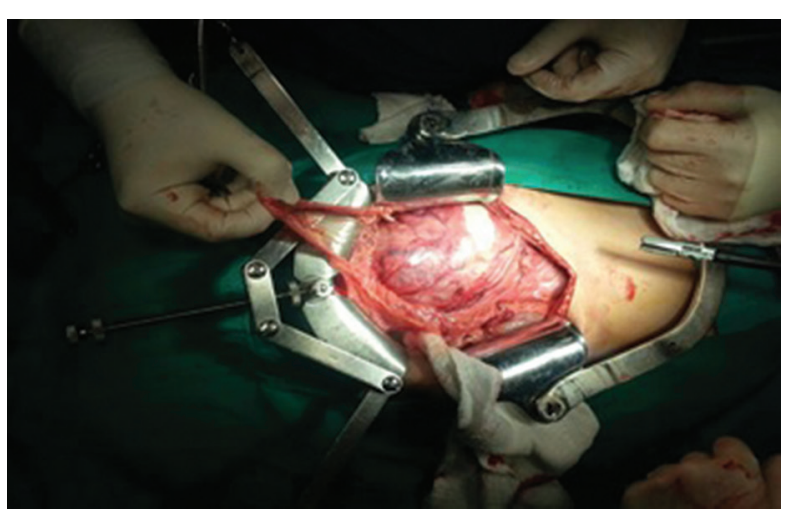

Figure 1. Laparotomy revealing the tumor in the head of the pancreas.

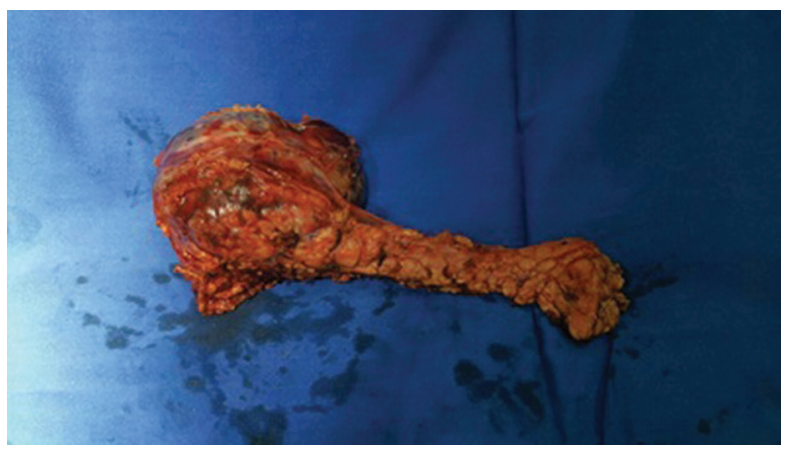

Figure 2. Surgical specimen showing the tumor implanted in the head of the pancreas.

CEA and CA 19-9 values were non-remarkable. A laparoscopic distal pancreatectomy with splenic preservation was performed. Discharge was given on post-operative day 4, without any complications. The pathology report was positive for a pseudopapillary neoplasm of $85 \times 90 \mathrm{~mm}$, with free surgical margins (Fig. 2). The last control of the patient was at 34 months with CT that did not show recurrence.

\section{Case 3}

An 18-year-old female patient with a history of acute pancreatitis of biliary origin was found to have a heterogeneous solid nodular image of $43 \mathrm{~mm}$ in diameter located in the middle segment of the pancreas in an abdominal ultrasound and $\mathrm{CT}$, tumor markers were CEA $0.8 \mathrm{U} / \mathrm{ml}$ and Ca 19-93.0 U/ml. A laparoscopic distal pancreatectomy with splenic preservation was performed, using the Warshaw technique. The biopsy reported solid pseudopapillary neoplasm of $50 \times 45$ $\times 30 \mathrm{~mm}$, free surgical margins, positive CD 10, CD56, and PR. Discharge was given at day 8. Follow up at 30 months did not show recurrence. 
Table 1. Table describing the cases

\begin{tabular}{|c|c|c|c|c|c|}
\hline Cases & Symptoms & Imaging & Treatment & Immunohistochemistry & Evolution \\
\hline 1 & $\begin{array}{l}\text { Epigastric pain and } \\
\text { elevation of liver } \\
\text { enzymes without } \\
\text { cholestasis }\end{array}$ & $\begin{array}{l}\text { MRI: } 3 \mathrm{~cm} \text { lesion } \\
\text { in the head of the } \\
\text { pancreas }\end{array}$ & $\begin{array}{l}\text { Open } \\
\text { pancreaticoduodenectomy }\end{array}$ & $\begin{array}{l}\text { Alfa-1-antitripsin, } \\
\text { Vimentin, CD-10, CD-56, } \\
\text { and progesterone } \\
\text { receptor + }\end{array}$ & $\begin{array}{l}34 \text { months follow-up without } \\
\text { recurrence at CT }\end{array}$ \\
\hline 2 & $\begin{array}{l}\text { Lumbar pain } \\
\text { Incidental finding }\end{array}$ & $\begin{array}{l}\text { CT: } 10 \mathrm{~cm} \text { lesión in } \\
\text { páncreas body with } \\
\text { áreas of necrosis }\end{array}$ & $\begin{array}{l}\text { Laparoscopic distal } \\
\text { pancreatectomy with } \\
\text { splenic preservation }\end{array}$ & $\begin{array}{l}\text { Alfa-1-antitripsin, CD-10, } \\
\text { CD-56, and progesterone } \\
\text { receptor + }\end{array}$ & $\begin{array}{l}30 \text { months follow-up without } \\
\text { recurrence at CT }\end{array}$ \\
\hline 3 & Acute pancreatitis & $\begin{array}{l}\text { CT: heterogenic solid } \\
\text { nodular image of } \\
43 \mathrm{~mm} \text { located in the } \\
\text { body of the pancreas }\end{array}$ & $\begin{array}{l}\text { Laparoscopic distal } \\
\text { pancreatectomy with } \\
\text { splenic preservation }\end{array}$ & $\begin{array}{l}\mathrm{CD} 10, \mathrm{CD} 56 \text {, and } \\
\text { progesterone receptor + }\end{array}$ & $\begin{array}{l}24 \text { months follow-up without } \\
\text { recurrence }\end{array}$ \\
\hline 4 & $\begin{array}{l}\text { Palpable epigastric } \\
\text { tumor }\end{array}$ & $\begin{array}{l}\text { CT: solid cystic lesion } \\
\text { in the head of the } \\
\text { pancreas }\end{array}$ & $\begin{array}{l}\text { Open } \\
\text { splenopancreatectomy }\end{array}$ & $\begin{array}{l}\text { Alfa-1-antitripsin, CD-10, } \\
\text { CD-56, and progesterone } \\
\text { receptor + }\end{array}$ & $\begin{array}{l}20 \text { months follow-up without } \\
\text { recurrence }\end{array}$ \\
\hline 5 & Epigastric pain & $\begin{array}{l}\text { CT: lesion in the head } \\
\text { of the pancreas }\end{array}$ & $\begin{array}{l}\text { Open } \\
\text { pancreaticoduodenectomy }\end{array}$ & $\begin{array}{l}\text { Alfa-1-antitripsin, CD-10, } \\
\text { CD-56, and progesterone } \\
\text { receptor + }\end{array}$ & $\begin{array}{l}\text { Hepaticojejunostomy } \\
\text { stenosis, requiring } \\
\text { percutaneous dilatation. } \\
\text { Stump pancreatitis at } 24 \\
\text { months, without recurrence. }\end{array}$ \\
\hline 6 & Incidental finding & $\begin{array}{l}\text { CT: hypodense } \\
\text { nodule in the head of } \\
\text { the pancreas }\end{array}$ & $\begin{array}{l}\text { Open } \\
\text { pancreaticoduodenectomy }\end{array}$ & $\begin{array}{l}\text { Alfa-1-antitripsin, CD-10, } \\
\text { CD-56, and progesterone } \\
\text { receptor + }\end{array}$ & $\begin{array}{l}21 \text { months follow-up without } \\
\text { recurrence at CT }\end{array}$ \\
\hline
\end{tabular}

\section{Case 4}

A 14-year-old female patient, otherwise healthy, consulted for a palpable non-painful abdominal mass. The CT showed a $10 \mathrm{~cm}$ solid cystic lesion in the body of the pancreas, without metastases tumor markers were CA 19-92.8 U/ml. Open distal pancreatectomy without splenic preservation was performed (Fig. $3 \mathrm{~A}$ and B). The pathology report confirmed a $116 \times 130$ $\times 75 \mathrm{~mm}$, pseudopapillary neoplasm compatible with Frantz tumor with free surgical margins, positive alpha-1-antitrypsin, CD-10, CD-56, and PR. Control at 20 months without recurrence.

\section{Case 5}

A 23-year-old female patient, previously healthy, consulted for epigastric pain tumor markers were CA 19-93.2 U/ml. CT showed solid cystic lesion in the head of pancreas, without infiltration of the bile duct, Wirsung duct, or mesenteric vessels, neither evidence of metastases (Fig. 4-5). An open pancreatoduodenectomy was performed. Histopathological analysis confirmed a solid pancreatic pseudopapillary neoplasm $26 \times 25 \mathrm{~mm}$, positive alpha-1-antitrypsin,

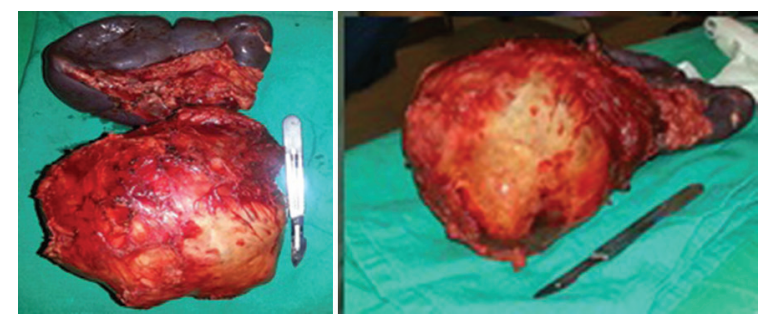

Figure 3. A-B: surgical specimen showing the large size of the tumor in the body and tail of the pancreas.

CD-10, CD-56, and PR. At the first month of follow up after surgery, labs showed elevated liver enzymes, abdominal ultrasound showed dilation of the intra hepatic bile duct, secondary to stenosis of the hepatijejuno-anastomoses, confirmed by MRI. A percutaneous dilatation of the stenosis was performed. At 20 months, the patient presented with an episode of mild acute pancreatitis Balthazar A, without relapse of disease.

\section{Case 6}

In a surveillance CT of a 34-year-old female with a history of breast cancer treated with surgery and chemoradiation, a $20 \times 18$ cystic lesion was found in the head 

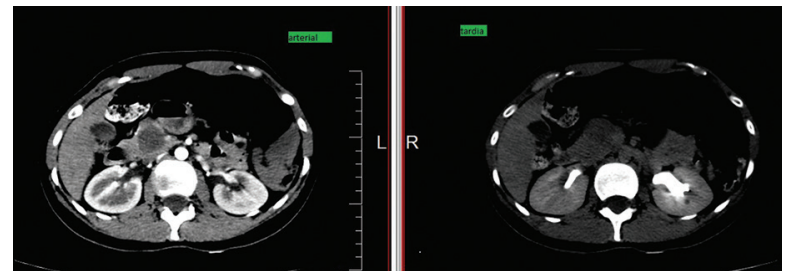

Figure 4. Axial computed tomography scan of the abdomen with contrast, showing a hypodense cystic mass in the head of the pancreas, with poorly defined edges and lobed with mass effect of the surrounding tissue. Arterial and venous phase.

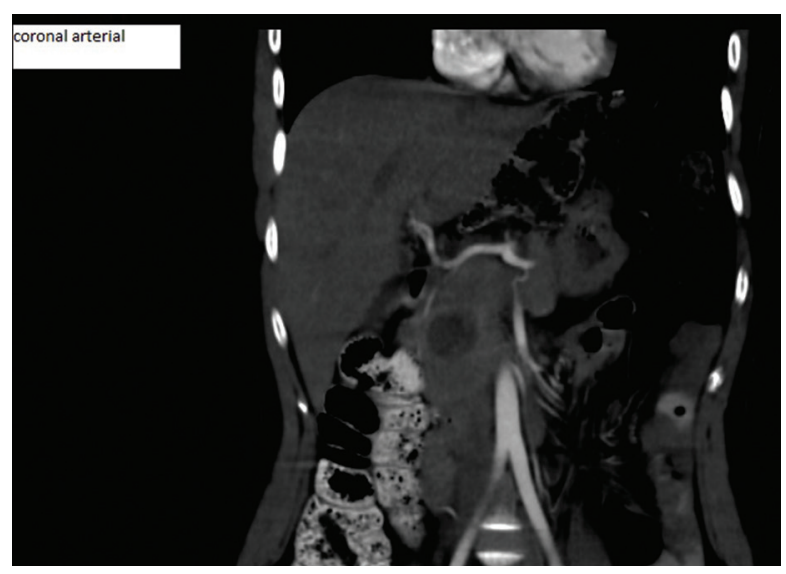

Figure 5. Computed tomography scan of the coronal arterial phase, solid mass with predominant hypodense necrotic area after contrast administration, with the displacement effect of adjacent structures.

of the pancreas without extraglandular involvement a hypodense, $20 \times 18 \mathrm{~mm}$, nodular lesion with cystic components located in the head of the pancreas, without extraglandular involvement was found. These findings were confirmed by MRI. Laboratory was non remarkable, and CA 19-9 was $9 \mathrm{U} / \mathrm{ml}$. A pancreaticoduodenectomy was performed. The pathology report confirmed a solid pseudopapillary pancreatic neoplasm, free margins, positive alpha-1-antitrypsin, CD-10, CD-56, and PR. The patient was discharged on day 7 without complications. No relapse was recorded at 21-month follow-up.

\section{Discussion}

Solid pseudopapillary tumor of the pancreas is a rare entity that accounts for about $1 \%$ of all pancreatic tumors, being more frequent in women (W/M 10:1) between the $2^{\text {nd }}$ and $4^{\text {th }}$ decades of life, although up to $20 \%$ of cases can occur in pediatric patients ${ }^{1-8}$.

Although it can reach sizes of more than $10 \mathrm{~cm}$ and invade adjacent structures, it is a tumor with a good prognosis and the occurrence of metastasis is rare. Malignancy should be suspected in the presence of imaging signs suggestive of vascular, nervous, lymphatic, or hepatic metastasis ${ }^{9}$. In our experience, no metastases were recorded in our experience.

These are slow-growing tumors and their clinical presentation is varied, vague and non-specific. In our experience, $50 \%$ of the cases were incidental imaging findings. The mass effect can generate symptoms of compression, abdominal pain, and feeling of fullness. Isolated cases of rupture of the capsule with hemoperitoneum and acute abdomen have been described ${ }^{10}$. In cases located in the head of the pancreas, biliary obstruction is very rare, unlike adenocarcinomas.

The most frequent location is the head of the pancreas (30-40\%), followed by a frequency of $32 \%$ and $28 \%$ in body and tail, respectively ${ }^{1-8}$. The treatment must be adapted to the tumor location, surgical risk, and the possibility of achieving complete resection $(\mathrm{R} 0)$. In our series, we presented three cases in the head of the pancreas and three in the body, then three pancreaticoduodenectomies and three distal pancreatectomies were performed.

Regarding additional tests, the laboratory does not usually show alterations and the tumor markers are rarely altered ${ }^{11}$. Abdominal ultrasound is the first-line diagnostic method because it is readily accessible and minimally invasive, with no need to irradiate the patient. It allows the identification of lesions in solid organs, often incidentally ${ }^{12}$, however, it must be complemented with CT and MRI, which are the preferred methods in case of suspected diagnosis, due to the characteristics of the tumor and the need of evaluation of the vascular invasion. On CT, an encapsulated mass with solid cystic components can be observed due to necrohemorrhagic degeneration, as well as calcifications in its periphery ${ }^{13}$. On the other hand, in nuclear magnetic resonance, it can be seen as a well-defined tumor with solid isointense areas with the pancreas in $\mathrm{T} 1$ or a signal slightly high in T2. The cystic areas appear as high-intensity signals in $\mathrm{T} 1^{14}$.

It is very important to consider pancreatic pseudocysts as a differential diagnosis, since $60 \%$ of these resolve spontaneously. In the presence of a suspicious lesion and in the absence of a history of acute pancreatitis, it is convenient to consider it as a cystic neoplasm, without delaying the surgical intervention ${ }^{15}$.

Regarding surgery, the laparoscopic approach is valid and also facilitates splenic preservation in tumors located in the body and/or tail. In a comparative study 
between laparoscopic distal pancreatectomy versus the open technique, it was demonstrated that the laparoscopic technique is associated with less blood loss, a better post-operative recovery in terms of shorter hospital stay, lower risk of general postoperative complications, and infection of the surgical wound ${ }^{16}$. Our experience is consistent with the literature in this regard.

Among the techniques of splenic preservation, Kimura's technique consists of maintaining the integrity of the anatomy of the splenic artery and vein, whether Warshaw's allows the vascular viability of the spleen in cases of splenic artery and vein ligation through the integrity of the short gastric and gastroepiploic vessels in their paths into the splenic hilum ${ }^{17}$. The preservation of the spleen, using the Warshaw technique, allows a pancreatic resection surgery with a significantly shorter operative time and blood losses significantly lower than those of the technique that tries to maintain the integrity of the splenic vessels ${ }^{18}$. Ten retrospective studies involving 699 patients showed that the Warshaw technique was associated with a shorter operative time $(p<0.0001)$. There were no differences in blood loss $(p<0.45)$. However, the appearance of gastric varices and splenic infarction was significantly higher in the group of the Warshaw techniqu ${ }^{17-19}$. In our experience, both techniques showed good results.

Splenic preservation is not free of complications as portal thrombosis, infarction, splenic abscess, and hemorrhage have been reported ${ }^{18}$.

Other differential diagnoses are endocrine tumors, acinar cell carcinoma, pancreatoblastoma, ductal adenocarcinoma, and cystic tumors of the pancreas. Differential intraoperative diagnosis is often difficult, so immunohistochemical studies in pathological anatomy results are very important ${ }^{20}$.

The immunophenotype of this neoplasm is usually positive for vimentin $>90 \%$, alpha-1-antitrypsin $90 \%$, $>80 \%$ nonspecific enolase, CD-56, and PR. About $75 \%$ can express positivity for cyclin $D 1^{20,21}$. In our six cases, $100 \%$ were positive for CD-10, CD 56, and PR, $83.3 \%$ were positive for alpha-1-antitrypsin and only 1 case $(16.6 \%)$ was positive for vimentin.

In the results of pathology reports, venous invasion, perineural invasion, high nuclear grade, nests of necrotic tissue, and capsular invasion are factors of high malignant potential ${ }^{15}$.

The prognosis of these patients is considerably better than that of patients with equal invasion, but with a pancreatic tumor of another histological type. Resection is indicated even in the presence of liver metastases, since it has high survival aggressive management should always be used in patients in whom this type of tumor is suspected even when there is invasion of neighboring structures, or metastasi ${ }^{19}$. The estimated survival at 1.3 and 5 years is $99.4 \%$, $97.5 \%$, and $96.9 \%$, respectively ${ }^{13}$. The size of the tumor should not be a factor of unresectability.

\section{Conclusion}

Frantz tumor is a rare pancreatic neoplasm. Imaging findings are suggestive, but diagnostic confirmation is provided by histopathology and immunohistochemistry. They have a low malignant potential, and the gold standard of treatment is surgical excision ensuring free margins.

The laparoscopic approach is a safe and effective way of performing pancreatic surgery for the treatment of the left pancreas tumors. Both techniques SVP and WT are safe and feasible to preserve the spleen, although there is no significant benefit of one technique over the other. The choice between them must be made according to each case.

\section{Conflicts of interest}

The authors of this manuscript have no conflicts of interest.

\section{Ethical disclosures}

Protection of human and animal subjects. The authors declare that no experiments were performed on humans or animals for this study.

Confidentiality of data. The authors declare that they have followed the protocols of their work center on the publication of patient data.

Right to privacy and informed consent. The authors have obtained the written informed consent of the patients or subjects mentioned in the article. The corresponding author is in possession of this document.

\section{References}

1. Choi JY, Kim MJ, Kim JH, Kim SH, Lim JS, Oh YT, Chung JJ, et al. Solid pseudopapillary tumor of the pancreas: typical and atypical manifestations. AJR Am J Roentgenol. 2006;187:178-86.

2. Anzola AT, Jimenez DS. Frantz's tumor: the tumor of young women Pathological-radiological correlation of two cases on tomography review of the literature. Rev Fac Med. 2017;25:70-7.

3. Cai YQ, Xie SM, Ran X, Wang X, Mai G, Liu XB. Solid pseudopapillary tumor of the pancreas in male patients: report of 16 cases. World $\mathrm{J}$ Gastroenterol. 2014;20:6939-45.

4. Patil TB, Shrinkhande SV, Kanhere HA, Saoji RR, Ramadwar MR, Shukla PJ. Solid pseudopapillary neoplasm of the pancreas: a single institution experience of 14 cases. HPB (Oxford). 2006:8:148-50. 
5. Balthazar E, Subramanyan B, Lefleur R, Barone C. Solid and papillary epithelial neoplasm of the pancreas. Radiografic, CT, sonografic and angiographic features. Radiology. 1984;150:39-40.

6. Pettinato G, Manivel JC, Ravetto C. Papillary cystic tumor of the pancreas. A clinicopathologic study of 20 cases with cytologic, immunohistochemical, ultrastructural, and flow cytometric observations, and a review of the literature. Am J Clin Pathol. 1992;98:478-88.

7. Castro SM, Singhal D, Aronson DC, Busch OR, van Gulik TM, Obertop H, et al. Man-agement of solid-pseudopapillary neoplasms of the pancreas: a comparison with standard pancreatic neoplasms. World J Surg. 2007;31:1129-34

8. Machado MC, Machado MA, Bacchella T, Jukemura J, Almeida JL, Cunha JE. Solid pseudopapillary neoplasm of the pancreas: distinct patterns of onset, diagnosis and prognosis for male versus female patients. Surgery. 2008;143:29-34.

9. Angel-Fernandez J. Tumores quísticos del páncreas: revisión de la literatura. Cir Esp. 2003;73:297-308.

10. Aretxabala X, Rencoret G, Maluenda F, Fernández C, Csendes A. Tumor sólido pseudopapilar del páncreas: caso clínico. Rev Chil Cir. 2008:60:241-5

11. de Frantz-Gruber T. Un tumor sólido pseudopapilar del páncreas poco frecuente. Acta Méd Costarric. 2011:53:151-3.

12. Branco C, Vilaca S, Falcão J. Solid pseudopapillary neoplasm-case report of a rare pancreatictumor. Int J Surg Case Rep 2017;33:148-50.

13. Zhang $\mathrm{H}$, Liang TB, Wang $\mathrm{WL}$, Ren YG, Zheng SS. Diagnosis and treatment of solid-pseudopapillary tumor of the pancreas. Hepatobiliary Pancreat Dis Int. 2006;5:454-8.
14. Rubin G. Pancreatic microcystic adenoma presenting with acute hemoperitoneum: CT diagnosis. AJR Am J Roentgenol. 1991;156:749-55.

15. Cai YQ, Xie SM, Ran X, Wang X, Mai G, Liu XB. Solid pseudopapillary tumor of the pancreas in male patients: report of 16 cases. World $J$ Gastroenterol. 2014;20:6939-45.

16. Venkat R, Edil BH, Schulick RD, Lidor AO, Makary MA, Wolfgang CL. Laparoscopic distal pancreatectomy is associated with significantly less overall morbiility compared to the open technique. Ann Surg. 2012; 255:1048-59.

17. Warshaw AL. Conservation of the spleen with distal pancreatectomy. Arch Surg. 1988;123:5503.

18. Fernández-Cruz L, Martínez I, Gilabert R, César-Borges G, Astudillo E, Navarro S. Laparoscopic distal pancreatectomy combined with preservation of the spleen for cystic neoplasms of the pancreas. J Gastrointest Surg. 2004;8:493-501.

19. Yu Z, Li H, Jin C, Fu D, Di Y, Hao D, et al. Splenic vesse preservation versus Warshaws thechnique, during spleen-preservating, distal pancreatectomy: a meta-analysisand systematic review. Langerbecks Arch Surg. 2015;400:183-91.

20. Frantz VK. Tumors of the pancreas. In: Bum-berg CW, editors. Atlas of Tumor Pathology. $7^{\text {th }}$ ed. Washington, DC: Armed Forced Institute of Pathology; 1959. p. 32-3.

21. Pettinato G, Manivel JC, Ravetto C, Terraccian LM, Gould EW, di Tuoro A, et al. Papillary Cystic Tumor of the pancreas. A clinicopathologic study of 20 cases with cytologic, immunohistochemical, ultrastructural, and flow cytometric observations, and a review of the literature. Am J Clin Pathol. 1992;98(5):478-48. 